\title{
Everything is Going Electronic, so do Services and Service Quality: Bibliometric Analysis of E-Services and E-Service Quality
}

\author{
https://doi.org/10.3991/ijim.v15i18.24519 \\ Javed Ali ${ }^{1,2(\bowtie)}$, Ahmad Jusoh ${ }^{2}$, Norhalimah Idris ${ }^{2}$, \\ Alhamzah F. Abbas ${ }^{2}$, Ahmed H. Alsharif ${ }^{2}$ \\ ${ }^{1}$ Sukkur IBA University, Sindh, Pakistan \\ ${ }^{2}$ Universiti Teknologi Malaysia, Johor Bahru, Malaysia \\ javedali@iba-suk.edu.pk
}

\begin{abstract}
Purpose: The purpose of the study was to explore the developments in 'e-services and e-service quality' from 2000 to 2020. Data Source: Scopus database was used to conduct the bibliometric analysis of 404 documents. Method: VOSviewer software was used to analyse the research articles associated with 'e-services and e-service quality' research. Search was limited to keywords of 'e-services OR e-service and e-service quality'. Findings: Results revealed that the field of 'Business, Management and Accounting' had the highest number of publications. Total Quality Management and Business Excellence was found at the top among the most productive journals in chosen search. Chang W.-I. and Yuan S.-T. from Taiwan were found to be the leading authors among top ten authors. United States and National Cheng Kung University of Taiwan were found to be the leading country and institution in the selected search of e-service and e-service quality. Originality/Value: This study, to best of our knowledge, is the first of its kind in mapping the 'e-services and e-service quality' literature in Scopus. This will aid in shaping the central theme and set the future research directions for the researchers.
\end{abstract}

Keywords-e-services, e-service quality, bibliometric analysis

\section{$1 \quad$ Introduction}

Bibliometric analysis is a tool which is used to explore the trends and developments in the body of knowledge. It is the empirical and theoretical works of various researchers whose valuable contributions develop certain discipline, area or construct overtime [1], [2]. Bibliometric analysis is a quantitative approach which helps to identify and analyze the data related with keywords used and searched in the literature, their relationships, the number of articles published in a particular time frame and their 
citations [3]-[5]. The current paper is intended to review e-services and e-service quality research by using bibliometric technique.

Services are defined by Lovelock \& Wirtz, (2004), as "economic activities between two parties, implying an exchange of value between seller and buyer in a marketplace". When the services are performed in cyberspace such as using technologies, they are termed as e-services. As customers evaluate other services, they also evaluate e-services and their performances. Therefore, e-service quality is the consumer's evaluation and judgement of services in virtual markets and cyberspace [7].

Few studies had performed bibliometric analysis on service quality. Ali et al., [8] reviewed the concept of service quality in healthcare by using bibliometric analysis. Altıntaş et al., [9] used bibliometric analysis for e-tailing service. A review and bibliometric analysis of service quality, and customer satisfaction was conducted by Yas et al., [10] and they had used Scopus database. But to the best of our knowledge, this was the first bibliometric study on e-services and e-service quality. Therefore, the purpose of current paper was to explore and comprehend the trends and developments of e-services and e-service quality globally. Following research questions were addressed by the current paper.

RQ 1. What is the publication output of 'e-services and e-service quality' search across the years?

RQ 2. What are the most prominent authors and journals that contributed to the development of 'e-services and e-service quality' research?

RQ 3. What are the most productive institutions and countries in 'e-services and e-service quality' search?

RQ 4. What is the bibliometric mapping of 'e-services and e-service quality' search in terms of authors, countries, keywords, and documents?

\section{$2 \quad$ Method}

Bibliometric analysis is a technique utilized by researchers to understand the global trends of a chosen research area in the database of academic literature. It makes it different from the review paper which discusses the latest developments, challenges and critics, and future directions of a specific research area [2], [8].

\subsection{Data source \& search strategy}

The Scopus database was the source of data of the current study. It is considered as the largest citation and abstract database of peer-reviewed literature which cover a wide array of subjects [2], [5]. Data were extracted for the bibliometric analysis from the database from the date of May 20, 2021, to May 25, 2021. The search string was mainly focused on the central theme that was 'e-service quality'. It was further limited to exact keywords such as e-service quality, e-services, and e-service which resulted in 1002 documents. The oldest publication was found in the year 2000. Therefore, trend of publication was mentioned from 2000 till 2020. 
The search was then limited to document type - articles, source type - journals, language - English, and the year 2021 was excluded. The final documents were 404 which were utilized for the analysis. The search process flow is shown in the Figure 1 and the search string is given in Appendix 1.

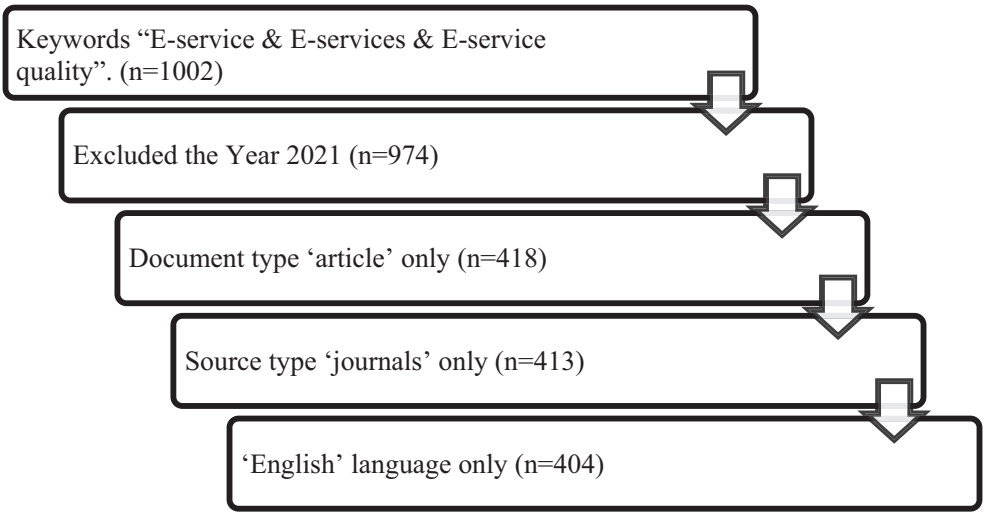

Fig. 1. Search process flow

\section{$3 \quad$ Analysis \& results}

We executed the bibliometric analysis on 404 documents. We analyzed the publication output across timeframe, the most productive journals and authors, the most prominent countries and institutions, contributions across different disciplines, co-authorship for authors and countries, co-occurrence of author keywords, and bibliographic coupling of documents.

\subsection{Publication output}

For the 20 years of search, 404 research papers had been published (Figure 2). The oldest paper was published in 2000 and the recent one was in 2020 as 2021 was excluded. Till 2005, less than 10 documents were published per year. After 2005, there was increasing number of publications in e-services and e-service quality research. In 2005, Parasuraman et al., [11] developed multi-item e-s-qual scale to measure e-service quality which could triggered the publications in said area. Overall trend of publication was increasing across the years. We found 2019 was the highest publication year with 46 documents. Most of the papers were published in the field of Business, Management and Accounting (27\%) followed by Computer Science $(26 \%)$ and Social Sciences (13\%). All other fields and subjects witnessed less than $10 \%$ in e-services and e-service quality research (Figure 3). 
Publication Output

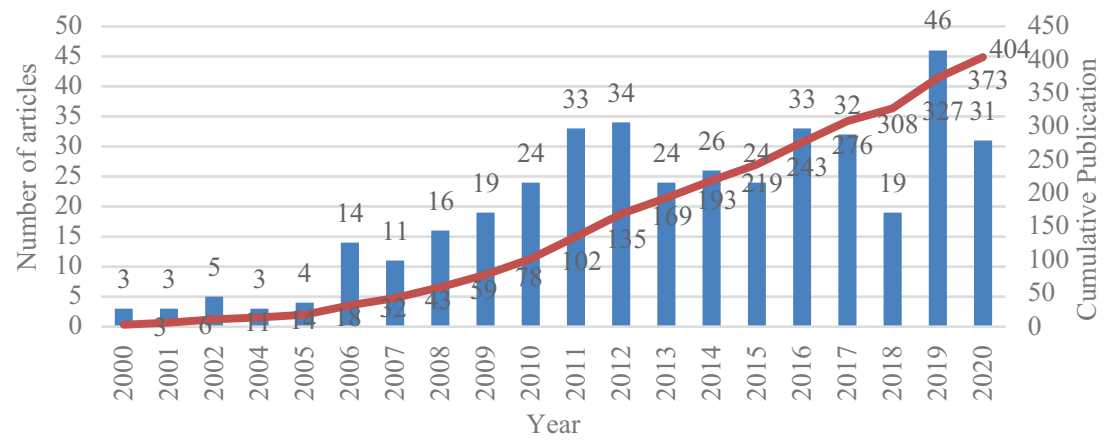

Fig. 2. Publication output

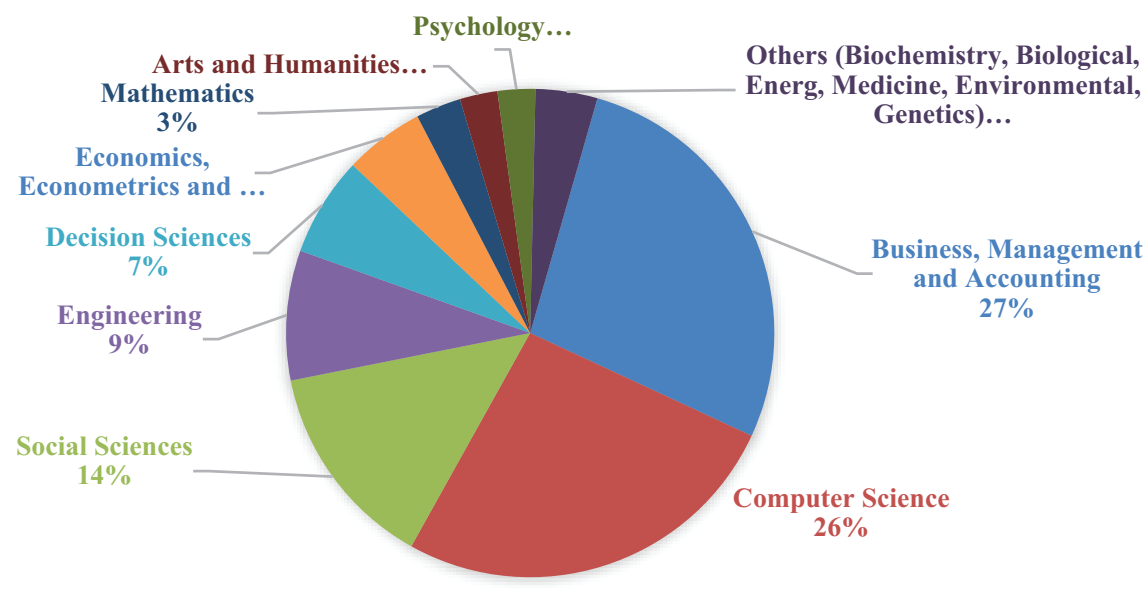

Fig. 3. Distribution of documents across subjects

\subsection{Most productive journals and prominent authors}

We analyzed the most productive journals and the most prominent authors in e-services and e-service quality research. Our results revealed the top 10 most productive journals and prominent authors in the 'e-services and e-service quality' research in Table $1 \&$ Table 2. Total Quality Management and Business Excellence was found at the top with the most publications with 4.6 cite score (2019) and it was published by Taylor and Francis. It was followed by Information Technology and People and Service Industries Journal, and they were published by Emerald and Taylor and Francis, respectively. All top ten journals were mentioned in Table 1. 
Table 1. List of top ten journals

\begin{tabular}{|c|c|c|c|c|c|c|}
\hline S/ No & Journal & $\begin{array}{l}\text { TP } \\
(\%)\end{array}$ & $\begin{array}{l}\text { Cite } \\
\text { Score } \\
2019\end{array}$ & The Most Cited Article & $\begin{array}{l}\text { Times } \\
\text { Cited }\end{array}$ & Publisher \\
\hline 1 & $\begin{array}{l}\text { Total Quality } \\
\text { Management } \\
\text { and Business } \\
\text { Excellence }\end{array}$ & 10 & 4.6 & $\begin{array}{l}\text { A. The impact of e-service } \\
\text { quality, customer } \\
\text { satisfaction and loyalty on } \\
\text { e-marketing: Moderating } \\
\text { effect of perceived value }\end{array}$ & 225 & $\begin{array}{l}\text { Taylor \& } \\
\text { Francis }\end{array}$ \\
\hline 2 & $\begin{array}{l}\text { Information } \\
\text { Technology and } \\
\text { People }\end{array}$ & 8 & 3.1 & $\begin{array}{l}\text { B. Factors influencing } \\
\text { consumer intention in social } \\
\text { commerce adoption }\end{array}$ & 55 & Emerald \\
\hline 3 & $\begin{array}{l}\text { Service } \\
\text { Industries } \\
\text { Journal }\end{array}$ & 8 & 3.3 & $\begin{array}{l}\text { C. Measuring the antecedents } \\
\text { of e-loyalty and the effect of } \\
\text { switching costs on website }\end{array}$ & 49 & $\begin{array}{l}\text { Taylor \& } \\
\text { Francis }\end{array}$ \\
\hline 4 & $\begin{array}{l}\text { Electronic } \\
\text { Government }\end{array}$ & 7 & 1.5 & $\begin{array}{l}\text { D. Significant socio- } \\
\text { economic factors for local } \\
\text { e-government development } \\
\text { in Portugal }\end{array}$ & 49 & Inderscience \\
\hline 5 & $\begin{array}{l}\text { Expert } \\
\text { Systems with } \\
\text { Applications }\end{array}$ & 7 & 11.0 & $\begin{array}{l}\text { E. A combined fuzzy AHP } \\
\text { and fuzzy TOPSIS based } \\
\text { strategic analysis of } \\
\text { electronic service quality } \\
\text { in healthcare industry }\end{array}$ & 262 & $\begin{array}{l}\text { Elsevier Top } \\
\text { of Form }\end{array}$ \\
\hline 6 & $\begin{array}{l}\text { Industrial } \\
\text { Management } \\
\text { and Data } \\
\text { Systems }\end{array}$ & 7 & 7.9 & $\begin{array}{l}F . \text { Determinants of satisfaction } \\
\text { and continuance intention } \\
\text { towards self-service } \\
\text { technologies }\end{array}$ & 158 & Emerald \\
\hline 7 & $\begin{array}{l}\text { International } \\
\text { Journal of } \\
\text { Services, } \\
\text { Technology and } \\
\text { Management }\end{array}$ & 6 & 0.4 & $\begin{array}{l}\text { G. Customer-based innovation } \\
\text { of knowledge e-services: } \\
\text { The importance of } \\
\text { after-innovation }\end{array}$ & 32 & Inderscience \\
\hline 8 & $\begin{array}{l}\text { Journal of } \\
\text { Internet } \\
\text { Commerce }\end{array}$ & 6 & 3.7 & $\begin{array}{l}\text { H. Consumer's Perception of } \\
\text { Website Service Quality: } \\
\text { An Empirical Study }\end{array}$ & 23 & $\begin{array}{l}\text { Taylor \& } \\
\text { Francis }\end{array}$ \\
\hline 9 & $\begin{array}{l}\text { Computers in } \\
\text { Human } \\
\text { Behavior }\end{array}$ & 5 & 12.1 & $\begin{array}{l}\text { I. What drives consumer } \\
\text { knowledge sharing in } \\
\text { online travel communities? } \\
\text { Personal attributes or } \\
\text { e-service factors? }\end{array}$ & 49 & Elsevier \\
\hline 10 & $\begin{array}{l}\text { Electronic } \\
\text { Commerce } \\
\text { Research and } \\
\text { Applications }\end{array}$ & 5 & 6.9 & $\begin{array}{l}J . \\
\text { How to design } \\
\text { personalization in a context } \\
\text { of customer retention: Who } \\
\text { personalizes what and to } \\
\text { what extent? }\end{array}$ & 49 & Elsevier \\
\hline
\end{tabular}

Our results revealed top ten authors who had contributed to the development in e-service and e-service quality. Chang W.-I. and Yuan S.-T. were at the top with total publication of 04 and both authors were from Taiwan. They were followed by Ba S. and Boyer K.K. from United States. All the facts regarding top ten authors were mentioned in table. 


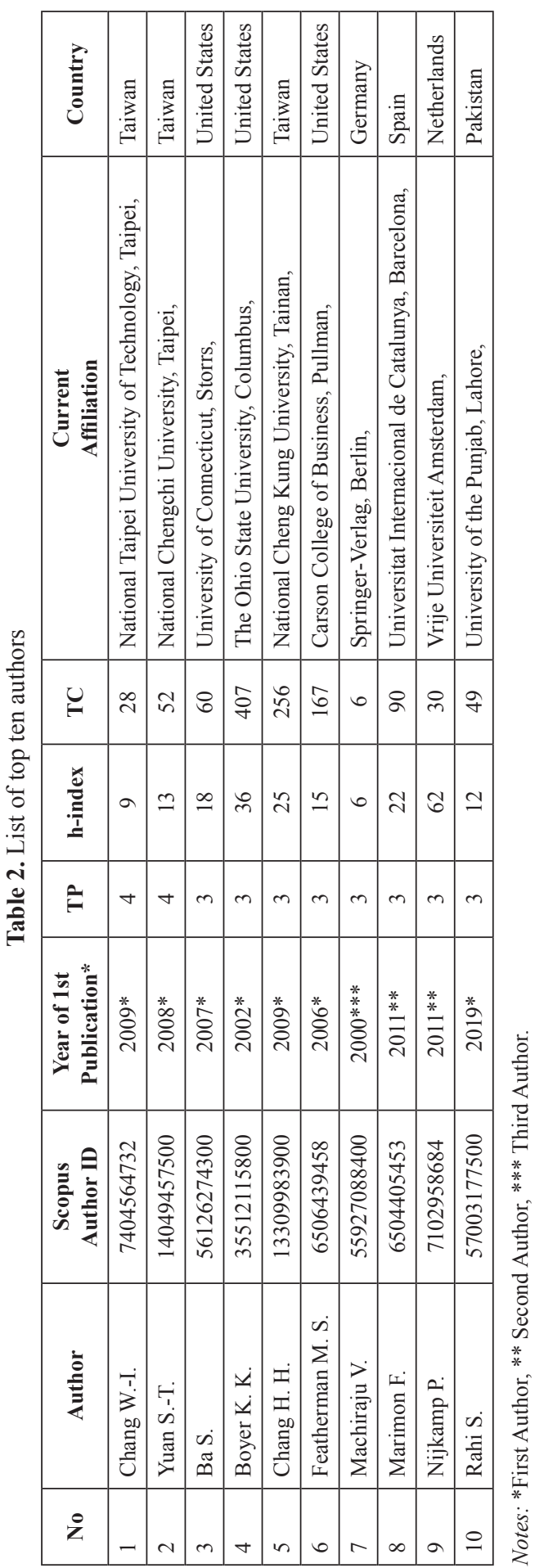




\subsection{The leading countries and institutions}

We analyzed the leading countries and institutions in our search. United States was found at the top with 76 total publications for countries (TPC). It was followed by Taiwan (TPC, 51) and India (TPC, 30). Other top countries were mentioned in Figure 4. Among the top ten institutions, National Cheng Kung University in Taiwan was leading the others with total publications (TPI) of 06, followed by Hewlett Packard Laboratories of United States with 05 TPI. Other leading institutions were mentioned in Figure 4.

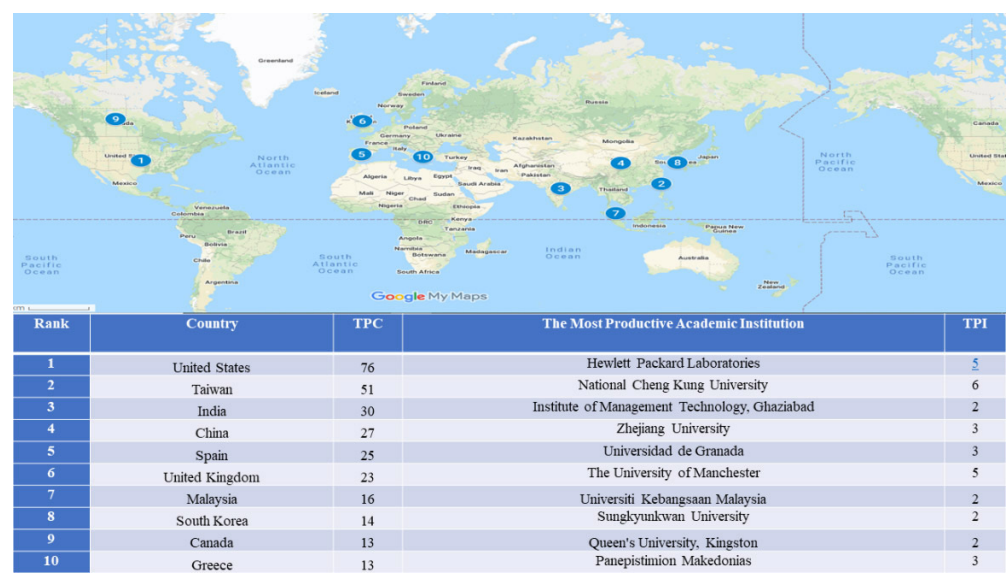

Fig. 4. Top countries and institutions

\subsection{Bibliometric maps}

VOSviewer (Centre for Science and Technology Studies, Leiden University, Netherlands) was the software that was used in mapping the literature of e-service quality research. It was a software which read the bibliometric maps pertaining to citations, author keywords and bibliographical information of databases. Maps include the items which represent the names of documents, authors, countries, and keywords. These items relate to each other by the link and its strength. This link is showed with positive numerical value. The higher the value, the higher the link strength between two items [12], [13], [14].

\subsection{Co-authorship (authors)}

The co-authorship analysis represents two authors contribute to a publication together. It is the link strength between two authors who have coauthored the number of publications. However, the total link strength (TLS) shows the total co-authorship strength of a selected author with other authors.

We applied different thresholds while executing co-authorship. Maximum number of authors per document was 25 . The minimum number of documents of an author was 01 , and minimum number of citations was remained 00. After applying these criteria, 
all the authors ( $\mathrm{n}=975)$ met the threshold. We found that Li H., Lu J., and Nijkamp P. had the highest total link strength (TLS) which was 09, followed by $\mathrm{Wu} \mathrm{D}$. who had got 8 TLS. All other details such as number of documents and citations of these authors and others were mentioned in Table 3.

Screenshots of the co-authors were created from two types of maps. Figure 5 represented the map of all authors included in the analysis $(n=975)$. It also contained the items which were not connected with other items. The layout for visualization of not connected set was set as its attraction value was 03 and repulsion was 02. Figure 6 represented the connected set of items (authors) which contained the largest connected set of 15 items (authors).

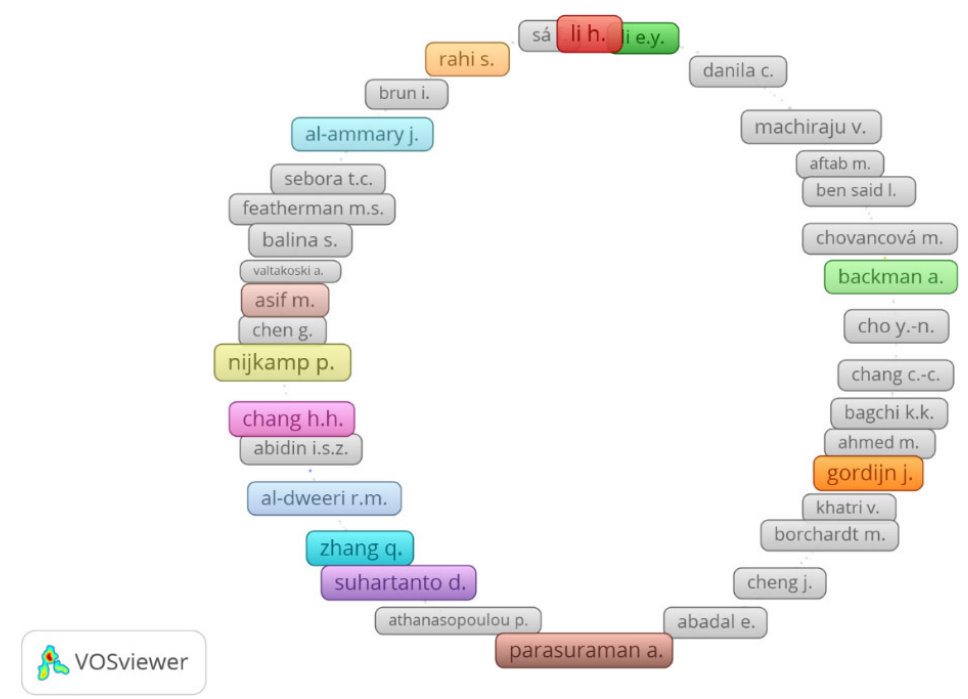

Fig. 5. Screenshot of co-authorship (Authors): not connected set

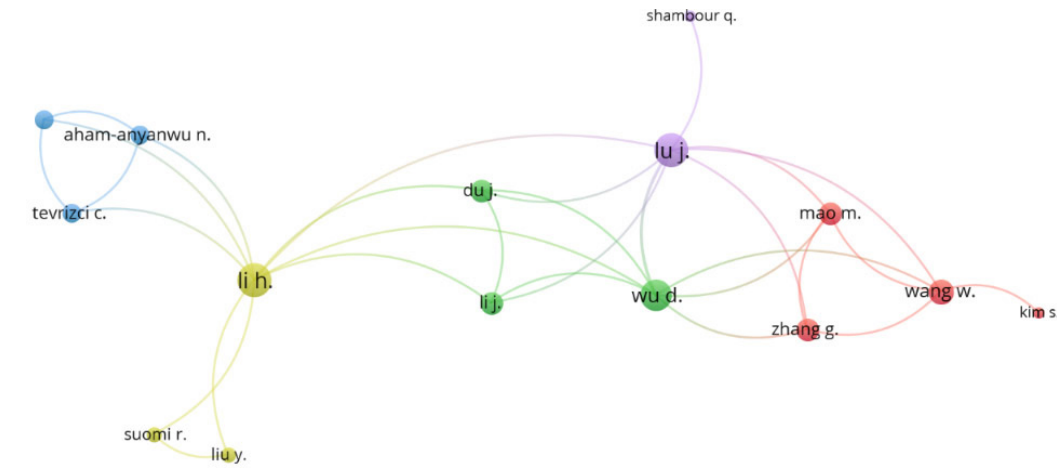

\& VOSviewer

Fig. 6. Screenshot of co-authorship (Authors): connected set 
Table 3. List of authors as per TLS

\begin{tabular}{|c|c|c|c|c|c|c|c|}
\hline Item (Author) & Documents & Citations & TLS & Item (Author) & Documents & Citations & TLS \\
\hline Li H. & 3 & 53 & 9 & Yin Q. & 1 & 24 & 6 \\
\hline Lu J. & 3 & 776 & 9 & Yuan S.-T. & 4 & 52 & 6 \\
\hline Nijkamp P. & 3 & 30 & 9 & Zarina L. & 2 & 1 & 6 \\
\hline Wu D. & 2 & 699 & 8 & Zhang Z. & 3 & 60 & 6 \\
\hline Chang H.H. & 3 & 256 & 7 & Zhou C. & 1 & 24 & 6 \\
\hline Gordijn J. & 2 & 15 & 7 & Agrawal V. & 2 & 7 & 5 \\
\hline Parasuraman A. & 2 & 1976 & 7 & Al-Ammary J. & 1 & 4 & 5 \\
\hline Suhartanto D. & 2 & 47 & 7 & Al-Kaabi R. & 1 & 4 & 5 \\
\hline Zhang Q. & 2 & 30 & 7 & Al-Soufi A. & 1 & 4 & 5 \\
\hline Al-Dweeri R.M. & 2 & 12 & 6 & Ali H. & 2 & 9 & 5 \\
\hline Alonso A. & 1 & 1 & 6 & Aljawder M. & 1 & 4 & 5 \\
\hline $\mathrm{Ba} \mathrm{S}$. & 3 & 60 & 6 & Alrayes A. & 1 & 4 & 5 \\
\hline Backman A. & 1 & 4 & 6 & Asif M. & 1 & 5 & 5 \\
\hline Balina S. & 2 & 1 & 6 & Brohman M.K. & 1 & 35 & 5 \\
\hline Barra E. & 1 & 1 & 6 & Bukhari M.H. & 1 & 5 & 5 \\
\hline Baumgarte D. & 2 & 1 & 6 & Chawla S. & 1 & 2 & 5 \\
\hline Bölte S. & 1 & 4 & 6 & Cho Y.-N. & 1 & 7 & 5 \\
\hline Chen Y.-C. & 3 & 44 & 6 & Choi C.S. & 1 & 7 & 5 \\
\hline Frostvittra M. & 1 & 4 & 6 & Hayes J.P. & 1 & 2 & 5 \\
\hline Gordillo A. & 1 & 1 & 6 & $\begin{array}{l}\text { Hernández- } \\
\text { Soriano F. }\end{array}$ & 2 & 13 & 5 \\
\hline Hirvikoski T. & 1 & 4 & 6 & Hussain A. & 1 & 5 & 5 \\
\hline Huang S. & 1 & 24 & 6 & Hwang J. & 1 & 5 & 5 \\
\hline Keith-Bodros G. & 1 & 4 & 6 & Jameel A. & 1 & 5 & 5 \\
\hline López-Pernas S. & 1 & 1 & 6 & Johnson J.H. & 1 & 2 & 5 \\
\hline Machiraju V. & 3 & 6 & 6 & Jr. & 1 & 2 & 5 \\
\hline Marco L. & 1 & 1 & 6 & $\begin{array}{l}\text { Kathawala } \\
\text { Y.A. }\end{array}$ & 1 & 2 & 5 \\
\hline Marimon F. & 3 & 90 & 6 & Kim K.H. & 1 & 7 & 5 \\
\hline Mellblom A. & 1 & 4 & 6 & Kim S.J. & 1 & 7 & 5 \\
\hline
\end{tabular}


Table 3. List of authors as per TLS (continued)

\begin{tabular}{|l|c|c|c|l|c|c|c|}
\hline Item (Author) & Documents & Citations & TLS & Item (Author) & Documents & Citations & TLS \\
\hline $\begin{array}{l}\text { Munoz- } \\
\text { Arcentales A. }\end{array}$ & 1 & 1 & 6 & Ko E. & 1 & 7 & 5 \\
\hline Neuts B. & 2 & 26 & 6 & Li L. & 2 & 29 & 5 \\
\hline $\begin{array}{l}\text { Norman- } \\
\text { Claesson E. }\end{array}$ & 1 & 4 & 6 & Martin P. & 1 & 35 & 5 \\
\hline Pozo A. & 1 & 1 & 6 & $\begin{array}{l}\text { Mirchandani } \\
\text { D.A. }\end{array}$ & 1 & 2 & 5 \\
\hline Quach D.-C. & 1 & 24 & 6 & Ouyang J. & 2 & 5 & 5 \\
\hline Rahi S. & 3 & 49 & 6 & Piccoli G. & 1 & 35 & 5 \\
\hline Romão J. & 2 & 26 & 6 & Sahito N. & 1 & 5 & 5 \\
\hline Sahai A. & 3 & 6 & 6 & Sarkees M.E. & 1 & 7 & 5 \\
\hline Skilters J. & 2 & 1 & 6 & Tripathi V. & 2 & 7 & 5 \\
\hline Stallaert J. & 3 & 60 & 6 & Wang W. & 2 & 681 & 5 \\
\hline Van Leeuwen E. & 2 & 26 & 6 & Watson R.T. & 1 & 35 & 5 \\
\hline Vasilakos A.V. & 1 & 24 & 6 & Zulkernine F. & 1 & 35 & 5 \\
\hline Xiong N. & 1 & 24 & 6 & & & & \\
\hline
\end{tabular}

\subsection{Co-authorship (countries)}

We then conducted co-authorship analysis for countries. It was the mapping of associations and affiliations among countries. Our results showed a total of 70 items in which few of the names were not representing any countries. Those names were excluded from the analysis. Thresholds were set as the minimum number of documents of a country was 01 and the minimum number of citations was 00 .

Maps of connected and not connected sets of items (countries) were shown in Figure 7 and Figure 8. The largest set of connected items (countries) was 47. Its layout values were based on attraction (05) and repulsion (02). For the map of not connected set, attraction and repulsion values were set on 06 and 01 , respectively. Result of co-authorship among countries revealed that United States was far ahead of other countries with total link strength (TLS) of 42 and 76 publications with 5226 citations. It was followed by China (TLS, 20; Documents, 27; Citations, 432) and United Kingdom (TLS, 20; Documents, 23; Citations, 492). The list of all countries and their association strength was mentioned in Table 4. 
Results also revealed some countries which did not collaborate with other countries in chosen research area. Brazil, Iraq, Denmark, Japan, Poland, Russian Federation, and others mentioned in table were among those countries which had 00 total link strength.

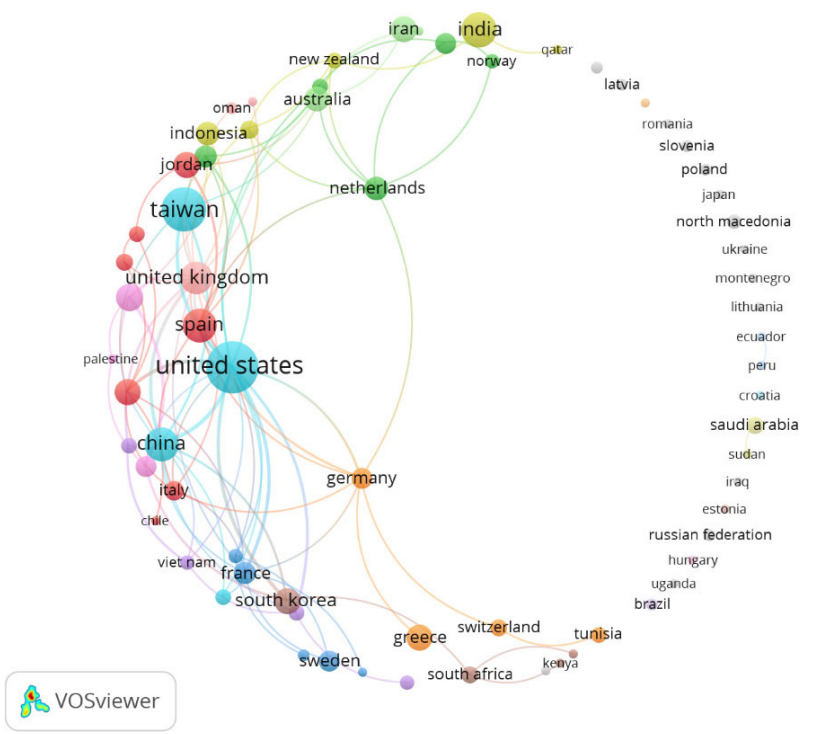

Fig. 7. Screenshot of co-authorship (Countries): not connected set

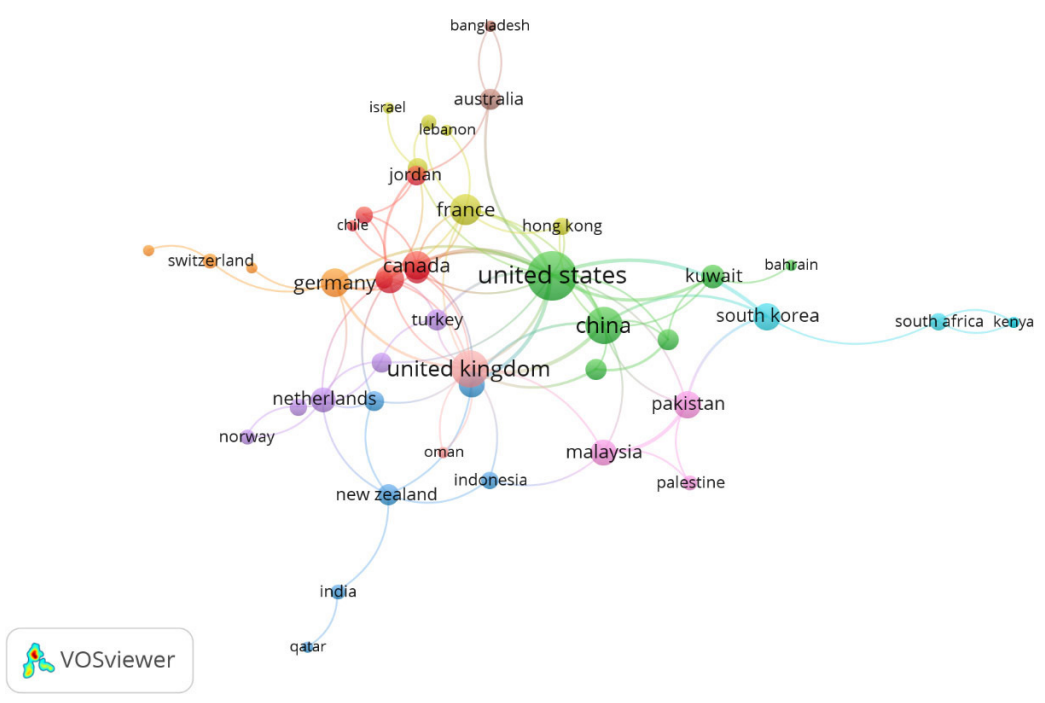

Fig. 8. Screenshot of co-authorship (Countries): connected set 

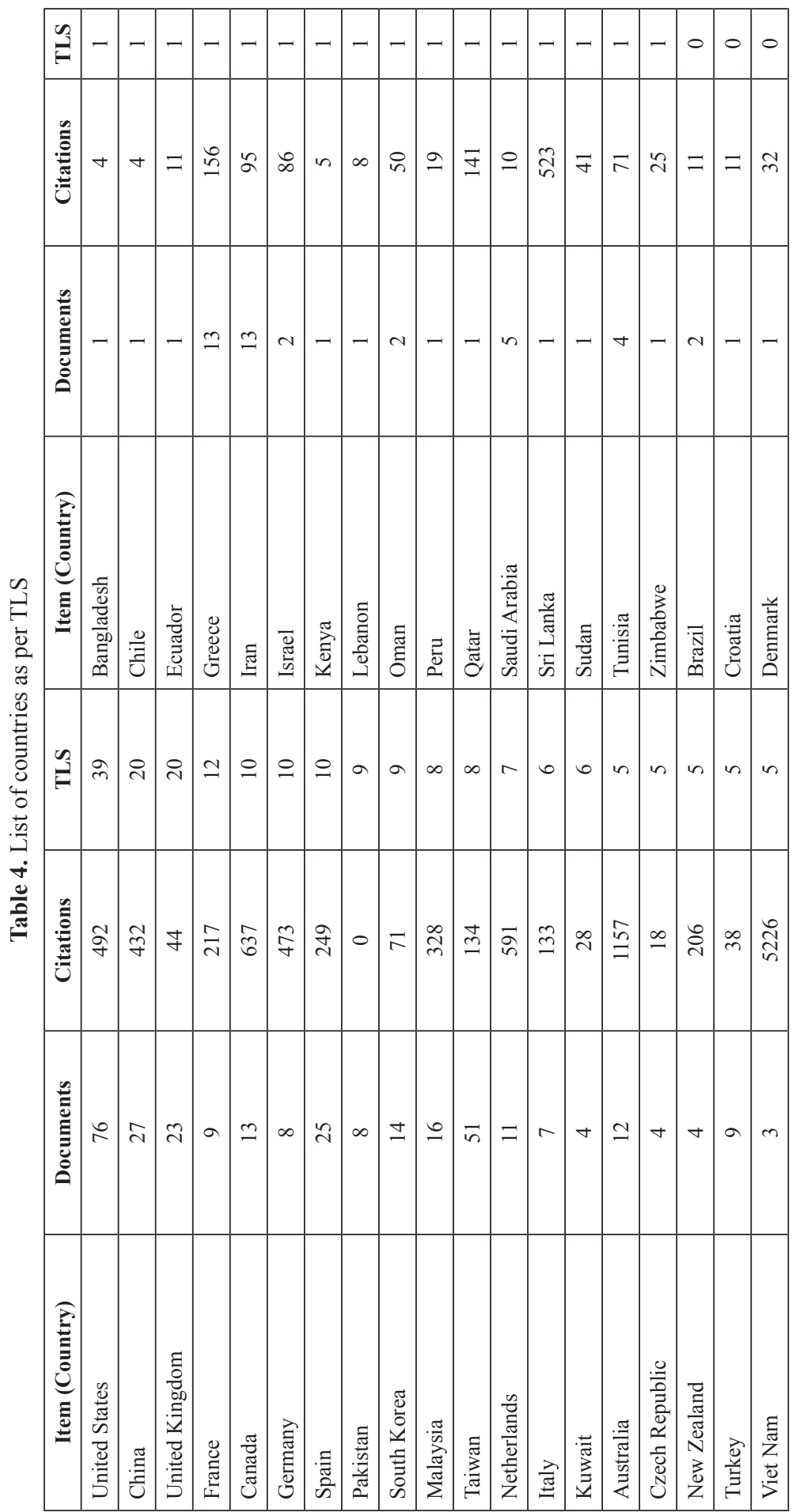


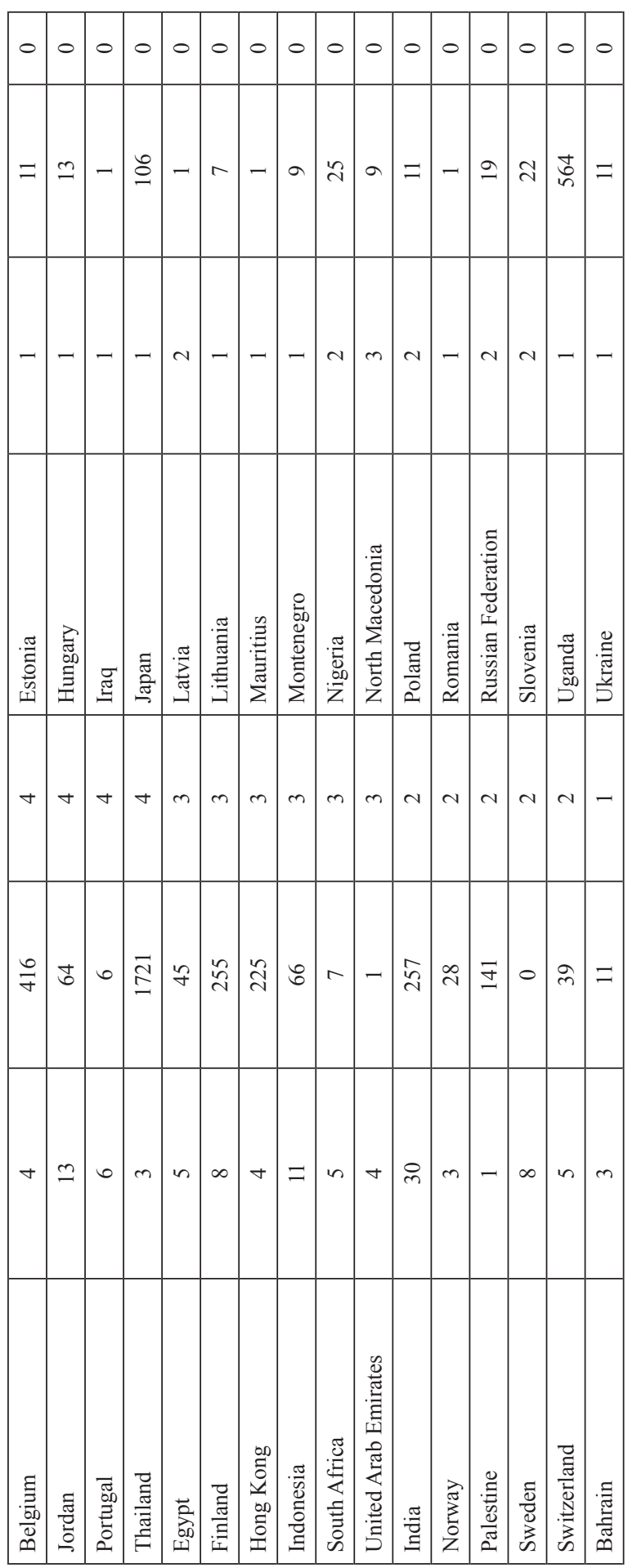




\subsection{Co-occurrence (author keywords)}

Co-occurrence analysis represents the occurrence of items in a particular document. We executed analysis on author keywords. Minimum occurrence threshold was set on 02 which gave us 194 author keywords out of 1071 for analysis. All the items (keywords) were connected so the largest set of these connected items was shown in Figure 9. The most prominent keywords found were hovering around e-services because it was the central theme. The keyword 'e-services' had 498 total link strength which occurred 217 times. It was followed by 'e-service quality' (Occurrence, 144; TLS, 362), 'e-commerce services' (Occurrence, 49; TLS, 141), 'customer satisfaction' (Occurrence, 34; TLS, 113), 'web services' (Occurrence, 32; TLS, 105) and 'e-government services' (Occurrence, 47; TLS, 100).

Results also showed different services (keywords) which were cooccurred with e-services and e-service quality search. The list of these services was mentioned in Table 5. We divided these services in two formats; ones were those which were related to electronic services and others were common services. The electronic services included online services, digital services, and mobile services.

Few electronic services were revealed to have least total link strength (TLS). These would be the interesting avenues for future research directions pertaining to e-services and e-service quality. Online delivery services occurred 02 times with 05 total link strength (TLS), followed by internet services (Occurrence, 02; TLS, 03) and online database services (Occurrence, 02; TLS, 02).

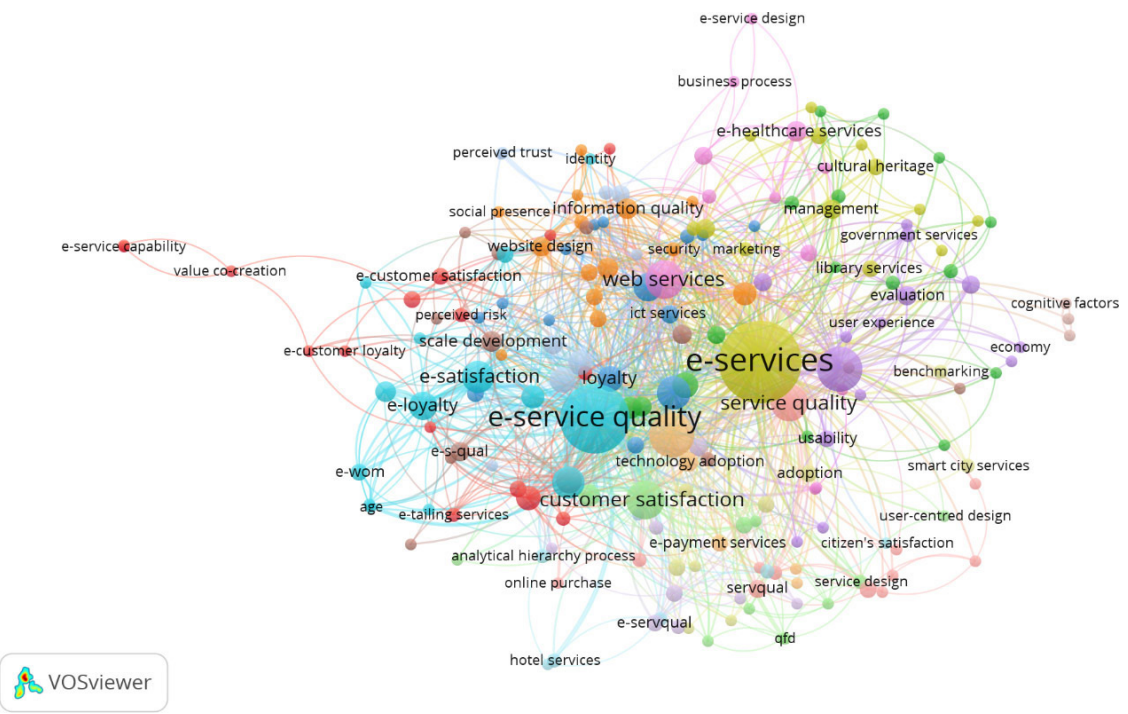

Fig. 9. Co-occurrence of author keywords 
Table 5. Categorization of e-services from co-occurrence of author keywords

\begin{tabular}{|l|c|c|l|c|c|}
\hline \multicolumn{2}{|c|}{ E-Services } & \multicolumn{2}{c|}{ Other Services } \\
\hline \multicolumn{1}{|c|}{ Item (Keyword) } & Occurrence & TLS & Item (Keyword) & Occurrence & TLS \\
\hline e-Commerce Services & 49 & 141 & Banking Services & 12 & 44 \\
\hline Web Services & 32 & 105 & Tourism Services & 6 & 25 \\
\hline e-Government Services & 47 & 100 & Education Services & 7 & 23 \\
\hline e-Banking Services & 21 & 76 & Healthcare Services & 5 & 15 \\
\hline e-Retailing Services & 12 & 38 & Government Services & 3 & 14 \\
\hline e-Healthcare Services & 7 & 17 & Retailing Services & 4 & 14 \\
\hline e-Tourism Services & 4 & 14 & Airline Services & 2 & 10 \\
\hline IT Services & 4 & 13 & Logistic Services & 3 & 10 \\
\hline ICT Services & 5 & 11 & Library Services & 4 & 8 \\
\hline e-Payment Services & 4 & 10 & Hotel Services & 3 & 7 \\
\hline e-Tailing Services & 3 & 10 & Insurance Services & 2 & 7 \\
\hline e-Communication Services & 2 & 9 & Atm Services & 2 & 6 \\
\hline Smart City Services & 3 & 7 & Delivery Services & 2 & 6 \\
\hline Online Delivery Services & 2 & 5 & & & \\
\hline Internet Services & 2 & 3 & & & \\
\hline Online Database Services & 2 & 2 & & & \\
\hline
\end{tabular}

\subsection{Bibliographic coupling (Documents)}

We proceed our analysis to bibliographic coupling of documents. Bibliographic coupling represents the links between publications. It also indicated the number of citations two publications have in common. We ran this tool on documents, there were other options like sources, authors, countries, and organizations.

While executing, we set the minimum number of citations of a document at 00 . All the documents (404) met the criteria. The largest set of connected items (documents) was 363 (figure). To make visualization better, attraction value was set at 4 and repulsion at -2 . Figure 10 represented the bibliographic coupling of 363 items (documents/ publications). It was based on the weight of total link strength. The 100 highest scoring TLS documents or publications were listed in Table 6. Stamenkov \& Dika, [13] was cited 6 times and had highest TLS (1909) among others, followed by del Águila-Obra et al., [14] and Poon \& Lee, [15] [18].

Figure 11 represented the bibliographic coupling map based on citations. It showed the prominence of Parasuraman et al., [11] with 199 links, 552 TLS and 1941 citations. It was highly cited publication in which authors created the multi-item scale that was e-s-qual for measuring e-service quality. 


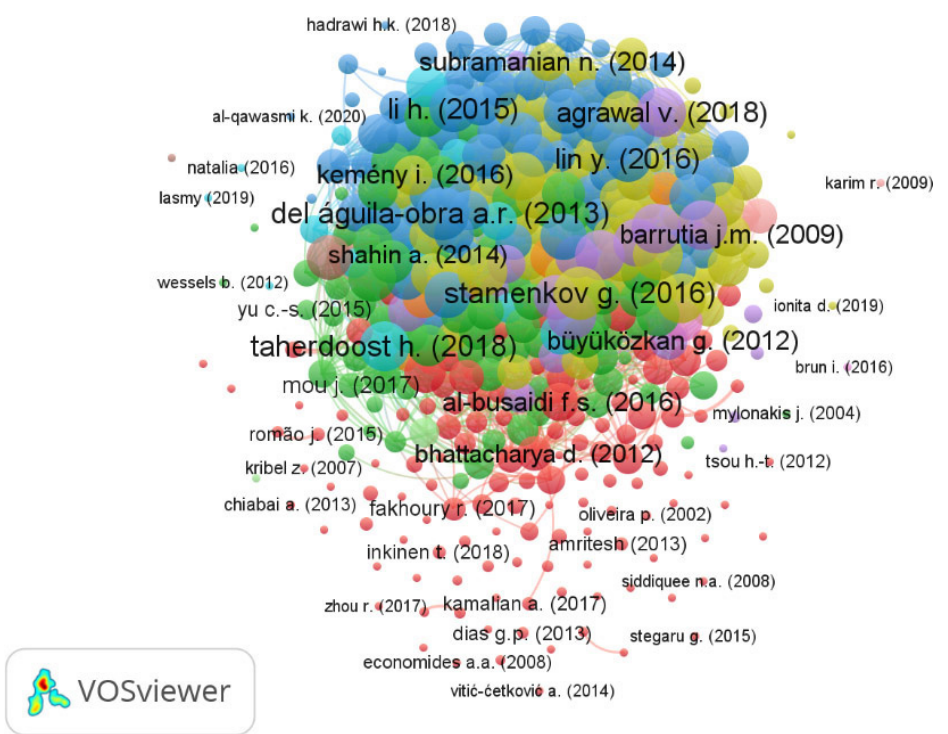

Fig. 10. Screenshot of bibliographic coupling (documents)

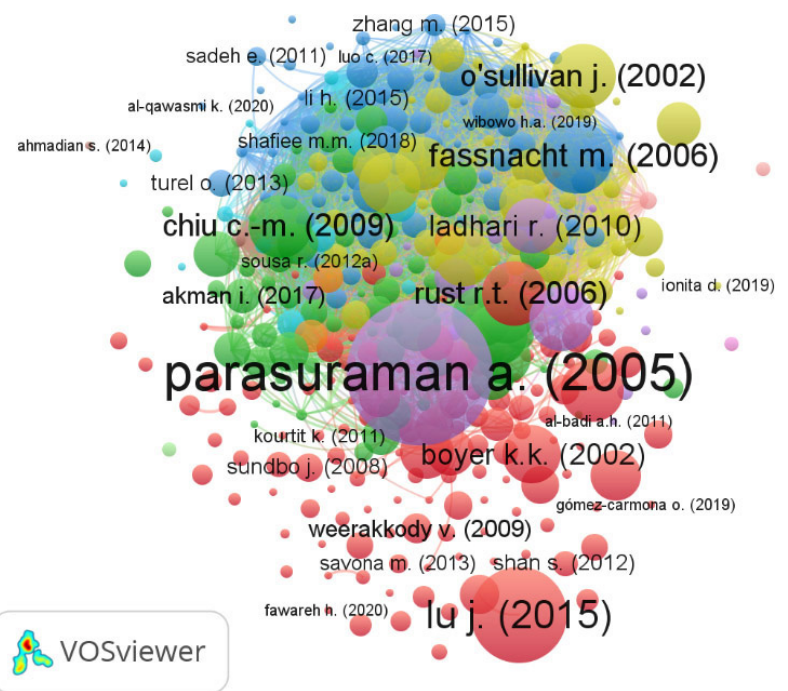

Fig. 11. Screenshot of bibliographic coupling (documents) on citations 
Table 6. List of documents from bibliographic coupling as per TLS

\begin{tabular}{|c|c|c|c|c|c|}
\hline Item (document) & Citations & TLS & Item (document) & Citations & TLS \\
\hline Stamenkov G. (2016) [13] & 6 & 1909 & Kemény I. (2016) & 13 & 918 \\
\hline $\begin{array}{l}\text { Del Águila-Obra A. R. } \\
\text { (2013) [14] }\end{array}$ & 0 & 1906 & Lin C.-H. (2010) & 17 & 914 \\
\hline Poon W.-C. (2012) [15] & 6 & 1640 & Du J. (2013) & 22 & 909 \\
\hline Shatnawi T. (2019) & 5 & 1629 & Mekovec R. (2007) & 11 & 900 \\
\hline Taherdoost H. (2018) & 33 & 1627 & Chiu C.-M. (2009) & 243 & 899 \\
\hline Hussien M.I. (2013) & 31 & 1622 & Khatib S.M. (2019) & 0 & 896 \\
\hline Gera R. (2011) & 20 & 1606 & Wang W. (2019) & 4 & 893 \\
\hline Agrawal V. (2018) & 6 & 1591 & Kumar G. (2017) & 11 & 891 \\
\hline Kaur B. (2020a) & 3 & 1585 & Lau T.-C. (2011) & 13 & 881 \\
\hline Shankar A. (2020) & 2 & 1584 & Tsang N.K.F. (2010) & 65 & 876 \\
\hline Janita M.S. (2013) & 60 & 1544 & Yaya L.H.P. (2011) & 63 & 874 \\
\hline Mouakket S. (2012) & 30 & 1499 & Rita P. (2019) & 43 & 869 \\
\hline Hsin Chang H. (2011) & 157 & 1489 & Finn A. (2009) & 61 & 869 \\
\hline Ladhari R. (2010) & 180 & 1471 & Trabelsi-Zoghlami A. (2020) & 4 & 867 \\
\hline Li H. (2015) & 23 & 1442 & Han B. (2018) & 9 & 847 \\
\hline Bhati N.S. (2020) & 0 & 1339 & Hsu S.-H. (2008) & 119 & 845 \\
\hline Al-Tarawneh K.A. (2012) & 13 & 1334 & Chang H.H. (2009) & 225 & 827 \\
\hline Ahmad A. (2016) & 23 & 1316 & Kumar A. (2015) & 10 & 819 \\
\hline Lin Y. (2016) & 29 & 1314 & Büyüközkan G. (2012) & 262 & 809 \\
\hline Mouakket S. (2014) & 7 & 1265 & Benaroch M. (2011) & 13 & 807 \\
\hline Park Y.A. (2007) & 85 & 1258 & Belanche D. (2014) & 79 & 798 \\
\hline Kim J.-H. (2020a) & 2 & 1190 & Jin J. (2020) & 0 & 797 \\
\hline Al-Nasser M. (2015) & 10 & 1171 & Al-Busaidi F.S. (2016) & 0 & 797 \\
\hline Al-Dweeri R.M. (2019) & 12 & 1156 & Subramanian N. (2014) & 59 & 788 \\
\hline Menezes L.S. (2016) & 8 & 1140 & Al-Ammary J. (2017) & 4 & 772 \\
\hline Stamenkov G. (2015) [13] & 21 & 1132 & Etemad-Sajadi R. (2015) & 29 & 772 \\
\hline Giovanis A.N. (2014) & 19 & 1129 & Hahn S.-E. (2017) & 27 & 769 \\
\hline Fuentes-Blasco M. (2010) & 49 & 1129 & Adil M. (2020) & 1 & 765 \\
\hline Rafiq M. (2012) & 28 & 1117 & Luo S.-F. (2011) & 9 & 763 \\
\hline Kaya B. (2019) & 17 & 1114 & Liao C.-H. (2011) & 37 & 757 \\
\hline Barrutia J.M. (2009) & 18 & 1110 & Zhang X. (2006) & 35 & 739 \\
\hline Lee F.-H. (2011) & 49 & 1105 & Castro-Lopez A. (2017) & 8 & 730 \\
\hline Xu J.D. (2013) & 199 & 1094 & Carlson J. (2011) & 30 & 727 \\
\hline Siu N.Y.-M. (2010) & 6 & 1083 & Kim J.-H. (2020b) & 0 & 720 \\
\hline Lee H. (2009) & 88 & 1077 & Hsu T.-H. (2012) & 30 & 719 \\
\hline Dai H. (2020) & 1 & 1072 & Rahi S. (2019c) & 13 & 717 \\
\hline Udo G.J. (2010) & 213 & 1051 & Ahmad S. (2020) & 2 & 716 \\
\hline
\end{tabular}

(Continued) 
Table 6. List of documents from bibliographic coupling as per TLS (continued)

\begin{tabular}{|l|c|c|l|c|c|}
\hline \multicolumn{1}{|c|}{ Item (document) } & Citations & TLS & \multicolumn{1}{|c|}{ Item (document) } & Citations & TLS \\
\hline Sardana S. (2020) & 1 & 1049 & Moez L. (2013) & 5 & 712 \\
\hline Yarimoglu E.K. (2017) & 7 & 1044 & Loukis E. (2012) & 30 & 711 \\
\hline Chen Y.-C. (2017) & 8 & 1041 & Hung S.-Y. (2013) & 28 & 704 \\
\hline Sousa R. (2012b) & 38 & 1025 & Agrawal V. (2019) & 1 & 695 \\
\hline Al-Adwan A.S. (2019) & 5 & 1012 & Kurt S.D. (2012) & 19 & 694 \\
\hline Sousa R. (2012a) & 7 & 1012 & Rahi S. (2019b) & 17 & 688 \\
\hline Stiglingh M. (2014) & 8 & 1009 & Liljander V. (2006) & 226 & 684 \\
\hline Ali H. (2019) & 5 & 987 & Rabinovich E. (2008) & 21 & 683 \\
\hline Kao T.-W. (2016) & 28 & 987 & Etemad-Sajadi R. (2014) & 14 & 670 \\
\hline O'cass A. (2012) & 40 & 986 & Taherdoost H. (2017) & 7 & 668 \\
\hline Rahman M.S. (2020) & 4 & 964 & Featherman M.S. (2010) & 34 & 659 \\
\hline Wu Y.-L. (2012) & 16 & 948 & Berbegal-Mirabent J. (2016) & 23 & 654 \\
\hline Pearson A. (2012) & 40 & 944 & Bhattacharya D. (2012) & 69 & 653 \\
\hline
\end{tabular}

\section{Conclusion, limitations and future research directions}

This study presented an overview of 'e-service and e-service quality' research. It was based on the 404 documents which were retrieved from the Scopus database with the timeline from 2000 to 2020. The field of 'Business, Management and Accounting' witnessed the highest number of publications. Total Quality Management and Business Excellence was found at the top among the most productive journals in chosen search. Chang W.-I. and Yuan S.-T. from Taiwan were found to be the leading authors among top ten authors. United States and National Cheng Kung University of Taiwan were found to be the leading country and institution in the selected search of e-service and e-service quality.

Bibliometric mapping results revealed Li H., Lu J., and Nijkamp P. were authors who had highest association between other authors, United States was the leading country which had highest associations, collaborations, and affiliations with other countries in authoring the studies. Furthermore, along with central keywords (e-services and e-service quality), e-commerce services, customer satisfaction, web services and e-government services were the most prominent and highly associated keywords found.

The current study was not free from limitations. The search term was limited to 'e-services and e-service quality' only, therefore, it might not cover all the relevant subject of studies. The current study excluded 2021 year which might include interesting topics in the searched area.

Based on the limitations and results, we found that most of the research was done in the field of Business, Management and Accounting, and there was a need to focus on other underexplored areas such as Psychology, Arts and Humanities, Decision Sciences and Engineering. These would be the interesting avenues for future research directions pertaining to e-services and e-service quality. Online delivery services, internet services 
and online database services were found least associated with central keywords and further research was suggested in those services.

\section{$5 \quad$ References}

[1] X. Li, E. Ma, and H. Qu, "Knowledge mapping of hospitality research - A visual analysis using CiteSpace,” Int. J. Hosp. Manag., vol. 60, pp. 77-93, 2017. https://doi.org/10.1016/j. ijhm.2016.10.006

[2] J. M. Khudzari, J. Kurian, B. Tartakovsky, and G. S. V. Raghavan, "Bibliometric analysis of global research trends on microbial fuel cells using Scopus database," Biochem. Eng. J., 2018, doi: https://doi.org/10.1016/j.bej.2018.05.002

[3] S. Evren and N. Kozak, "Bibliometric analysis of tourism and hospitality related articles published in Turkey," Anatolia, vol. 25, no. 1, pp. 61-80, 2014. https://doi.org/10.1080/130 $\underline{32917.2013 .824906}$

[4] F. Muñoz-Leiva, L. Porcu, and S. del Barrio-García, "Discovering prominent themes in integrated marketing communication research from 1991 to 2012: a co-word analytic approach," Int. J. Advert., vol. 34, no. 4, pp. 678-701, 2015. https://doi.org/10.1080/02650487.2015.10 $\underline{09348}$

[5] A. H. Alsharif, N. O. R. Z. M. D. Salleh, and R. Baharun, "Bibliometric Analysis," J. Theor. Appl. Inf. Technol., vol. 98, no. 15, 2020.

[6] C. H. Lovelock and J. Wirtz, "Services marketing: People, technology, strategy," 2004.

[7] J. Santos, "E-service quality: a model of virtual service quality dimensions," Manag. Serv. Qual. An Int. J., 2003. https://doi.org/10.1108/09604520310476490

[8] J. Ali, A. Jusoh, A. F. Abbas, and K. M. Nor, "Global Trends of Service Quality in Healthcare: A bibliometric analysis of Scopus Database.," J. Contemp. Issues Bus. Gov. Vol., vol. 27, no. 1, 2021.

[9] M. H. Altıntaş, S. Kılıç, and C. E. Akhan, "The transformation of the e-tailing field: a bibliometric analysis," Int. J. Retail Distrib. Manag., 2019. https://doi.org/10.1108/ IJRDM-10-2018-0232

[10] H. Yas, A. Jusoh, A. F. Abbas, A. Mardani, and K. M. Nor, "A review and bibliometric analysis of service quality and customer satisfaction by using Scopus database," Int. J. Manag., vol. 11 , no. 8, 2020.

[11] A. Parasuraman, V. A. Zeithaml, and A. Malhotra, "ES-QUAL: A multiple-item scale for assessing electronic service quality," J. Serv. Res., vol. 7, no. 3, pp. 213-233, 2005. https:// doi.org/10.1177/1094670504271156

[12] N. J. Van Eck and L. Waltman, "VOSviewer manual," Leiden: Univeristeit Leiden, vol. 1, no. 1, pp. 1-53, 2013.

[13] I. Mustapha, N. T. Van, M. Shahverdi, M. I. Qureshi, and N. Khan, "Effectiveness of Digital Technology in Education During COVID-19 Pandemic. A Bibliometric Analysis," Int. J. Interact. Mob. Technol., vol. 15, no. 8, pp. 136-154, 2021, doi: https://doi.org/10.3991/ijim. $\underline{\mathrm{v} 15 \mathrm{i} 08.20415}$

[14] N. Khan and M. I. Qureshi, "A systematic literature review on online medical services in Malaysia,” Int. J. online Biomed. Eng., vol. 16, no. 6, pp. 107-118, 2020, doi: https://doi. org/10.3991/ijoe.v16i06.13573

[15] G. Stamenkov and Z. Dika, "Bank employees' internal and external perspectives on e-service quality, satisfaction and loyalty," Electron. Mark., vol. 26, no. 3, pp. 291-309, 2016. https://doi.org/10.1007/s12525-016-0221-6 
[16] A.R. del Águila-Obra, A. Padilla-Meléndez, and R. Mohammad Al-dweeri, "Inputs and Outputs in the Quality of Electronic Services: Literature Review and Proposal of a Model of Relations," Innovar, vol. 23, no. 49, pp. 67-82, 2013.

[17] W.-C. Poon and C. K.-C. Lee, "E-service quality: an empirical investigation," J. Asia-Pacific Bus., vol. 13, no. 3, pp. 229-262, 2012. https://doi.org/10.1080/10599231.2012.690682

[18] M. I. Qureshi, N. Khan, S. M. Ahmad Hassan Gillani, and H. Raza, "A systematic review of past decade of mobile learning: What we learned and where to go," Int. J. Interact. Mob. Technol., vol. 14, no. 6, pp. 67-81, 2020, doi: https://doi.org/10.3991/ijim.v14i06.13479

\section{$6 \quad$ Appendix 1}

\subsection{Search String}

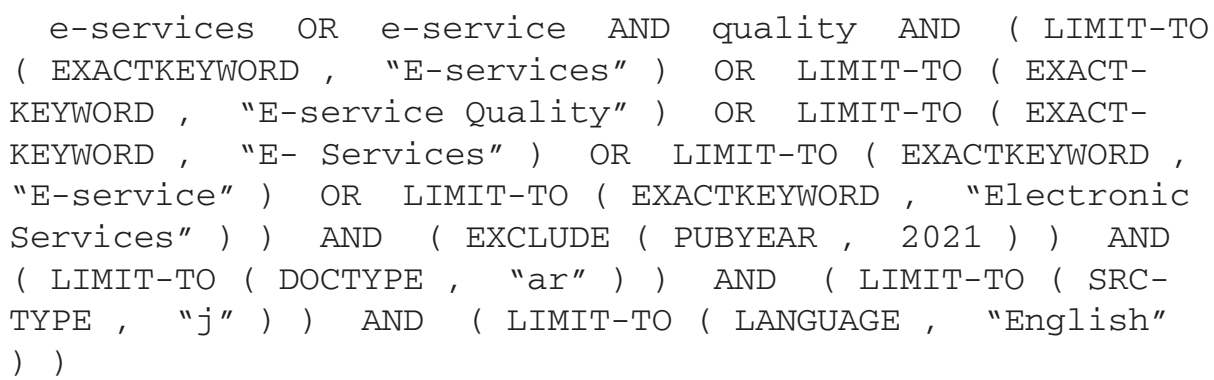

\section{Authors}

Javed Ali, Department of Business Administration, Sukkur IBA University, Sindh, Pakistan; Azman Hashim International Business School, Universiti Teknologi Malaysia. E-mail: javedali@iba-suk.edu.pk.

Ahmad Jusoh, Assoc. Professor and Senior Lecturer, Azman Hashim International Business School, Universiti Teknologi Malaysia. E-mail: ahmadj@utm.my.

Norhalimah Idris, Assoc. Professor and Senior Lecturer, Azman Hashim International Business School, Universiti Teknologi Malaysia. E-mail: norhalimah@utm.my.

Alhamza F. Abbas, Azman Hashim International Business School, Universiti Teknologi Malaysia. E-mail: alhamza.fadil@gmail.com.

Ahmed H. Alsharif, Azman Hashim International Business School, Universiti Teknologi Malaysia. E-mail: ahmedalsharif07@gmail.com.

Article submitted 2021-06-04. Resubmitted 2021-07-22. Final acceptance 2021-07-29. Final version published as submitted by the authors. 